All or Nothing 



\section{All or Nothing}

Systematicity, Transcendental Arguments, and Skepticism in German Idealism

\section{Paul W. Franks}

HARVARD UNIVERSITY PRESS

Cambridge, Massachusetts

London, England

2005 
Copyright (C) 2005 by the President and Fellows of Harvard College All rights reserved

Printed in the United States of America

Library of Congress Cataloging-in-Publication Data

Franks, Paul W., 1964-

All or nothing: systematicity, transcendental arguments, and skepticism in German idealism / Paul Franks.

p. $\mathrm{cm}$.

Includes bibliographical references and index.

ISBN 0-674-01888-5 (alk. paper)

1. Idealism, German. 2. Methodology-History-19th century. I. Title.

B2745.F73 2005

$141^{\prime} .0943-\mathrm{dc} 22 \quad 2005046184$ 